\title{
Structural Analysis of Steel Transmission Towers for Large River Crossing of Overhead Transmission Lines
}

\author{
A Case Study in Brazil
}

\author{
Mariana S. Rechtman \\ Civil Engineering Department \\ Fluminense Federal University \\ Niterói, Brazil \\ mariana.rechtman@gmail.com
}

\author{
Amauri Menezes \\ Batávia Engenharia \\ Niterói, Brazil \\ batavia@batavia.eng.br
}

\author{
Juliana N. M. Motta \\ Civil Engineering Department \\ Fluminense Federal University \\ Niterói, Brazil \\ juliana.motta@marteengenharia.com.br \\ José Guilherme S. da Silva \\ Structures and Foundations Department \\ Rio de Janeiro State University \\ Rio de Janeiro, Brazil \\ jgss@uerj.br
}

\author{
Orlando Longo \\ Civil Engineering Department \\ Fluminense Federal University \\ Niterói, Brazil \\ orlandolongo@gmail.com
}

\begin{abstract}
This study aims to investigate the structural behavior of steel transmission towers used for large river crossings. Design standards usually applied to analyze these structures don't consider situations in which the transmission towers are used in river crossings. In Brazil, due to the fact that it is necessary to cross large areas owing to the rivers' size, these towers assume great heights. It should be noted that the towers can weigh up to $24,500 \mathrm{kN}$ and exceed $300 \mathrm{~m}$ in height. The current study develops an analysis that surpasses the existing standard methodologies, aiming for a structural optimization compatible with vast crossings and new materials, aiming to resolve this design challenge regarding power transmission lines. To do this, a river crossing spanning $2,300 \mathrm{~m}$, situated in the northern region of Brazil, was studied based on the use of three different conductor configurations, electrically equivalent, commonly used wind design standards, and structural solutions utilizing tubular and angle profiles.
\end{abstract}

Keywords-steel transmission towers; power transmission lines; large river crossing

\section{INTRODUCTION}

Overhead transmission lines are used to transport high voltages between distant substations [1]. The expansion of the National Interconnected System (SIN) made compulsory the implementation of challenging projects, such as large river crossings in the Amazon region [3,4]. The main challenges of this type of projects are related to the physical dimensions of the venture, the regions of implementation, and the applied voltages, which can reach $800 \mathrm{kV}$ [2]. This type of project is characterized as essential and very relevant to the expansion of the SIN, enabling the interconnection of previously electrically isolated regions. Such regions depended essentially on thermal generation sources, which concentrate large $\mathrm{CO}_{2}$ emissions [3]. Figure 1 illustrates the large river crossing of the TucuruíMacapá-Manaus interconnection in the northern region of Brazil. Specific care is needed in the construction of transmission lines that cross the Amazon forest aiming to produce the least possible impact. Examples are the use of selfsupporting structures instead of guyed structures, occupying a smaller range of easement, as well as the adoption of higher structures, keeping the conductors' catenaries above the treetops, preserving the fauna and flora. Additionally, the transport of the structural elements must be carried out using rafts to avoid the construction of roads, in the midst of forest areas [5]. Regarding the execution of these projects, it is necessary to evaluate regional environmental parameters, local destructive wind activity, relative air density, atmospheric correction factors, and regional lightning activity intensity [6]. 
In addition, a detailed analysis is needed for insulation coordination procedures for voltages at $60 \mathrm{~Hz}$ and power surges, in order to determine safety distances, particularly considering operational safety requirements during construction [7]. Due to the size of the rivers, towers for river crossings need to overcome large areas, and as a consequence, they assume great heights. Therefore, these structures can weigh up to $24,500 \mathrm{kN}$, and can exceed $300 \mathrm{~m}$ in height [8].

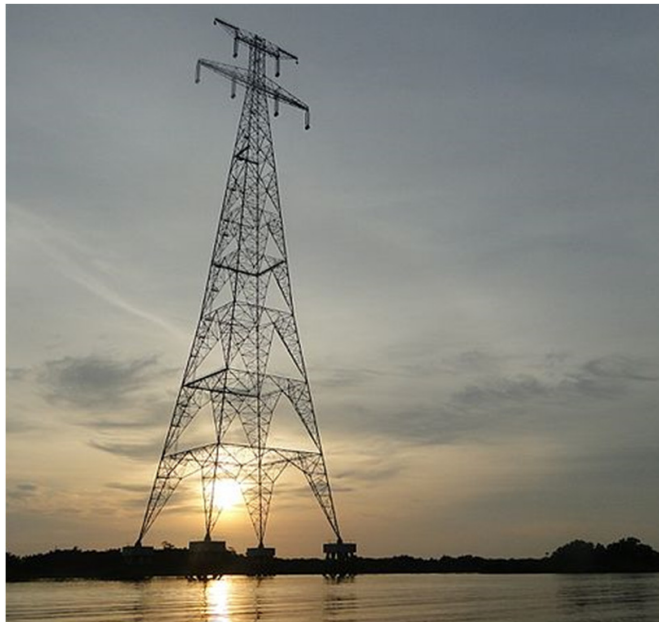

Fig. 1. Tower for large river crossing related to the Tucuruí-MacapáManaus interconnection.

Another relevant aspect is the current limitations in standards in relation to tower heights. For example, the commonly used IEC 60826 standard [9] is not accurate when calculating wind forces on a structure exceeding $60 \mathrm{~m}$ in height. Therefore, it is necessary to seek these definitions in other standards, such as $[10,11]$. Therefore, in this investigation, an analysis methodology was developed aiming for structural optimization compatible with existing large areas and with new available materials, based on the study of a $2,300 \mathrm{~m}$ river crossing, located at the northern region of Brazil. This research work presents the structural solutions based on the use of three different conductor configurations: 2xACCC Monte Carlo, 1xACCC 25mm, and 1xCALA 630 (AACSR), electrically equivalent, although with distinct mechanical characteristics. The three above-mentioned wind design standards were studied along with the structural solutions based on the use of tubular and angle profiles.

\section{ENVIROMENTAL PARAMETERS}

This section presents the methodologies applied to define the climatological and environmental data of the study area. Atmospheric correction factors, ceramic index, and wind speeds values were defined, having in mind studies of coordination and isolation of the investigated crossing. The interactions of the analyzed transmission line with the environment have received consistent attention. The values of the climatic parameters were quantified based on the data available from the National Institute of Meteorology (INMET): average temperatures, maximum and minimum temperatures, relative air density, atmospheric correction factors and lightning intensity levels were considered. Regarding the atmospheric correction factors, its inference followed the methodology presented in [12], added upon by the developments in the approach presented in [18]. The wind velocity was calculated based on the experimental measurements from INMET and the former DEPV (Department of Electronics and Flight Protection, Ministry of Aeronautics).

\section{A. Wind Velocities}

The wind velocities were defined based on the INMET and DEPV experimental data, considering the Gumbel statistical model and utilising the annual maximum speeds recorded over periods ranging from 4 to 17 years (Figures 2-4). The gust factor adopted for the region was $1.7 \mathrm{pu}$ for an average time of $3 \mathrm{~s}$, and $1.35 \mathrm{pu}$ for $30 \mathrm{~s}$. The variation coefficients of the maxima series vary from $13 \%$ to $19 \%$. Such values come from a parametric regionalization carried out through a weighted average using the collection time of each station. The Gumbel model is widely used in Brazil for several decades and its formulation can be found in detail in [9]. Traditionally, power surges are associated with wind velocity which has a return period of 2 years while an average time of $30 \mathrm{~s}$ has been considered in establishing safety distances [13].

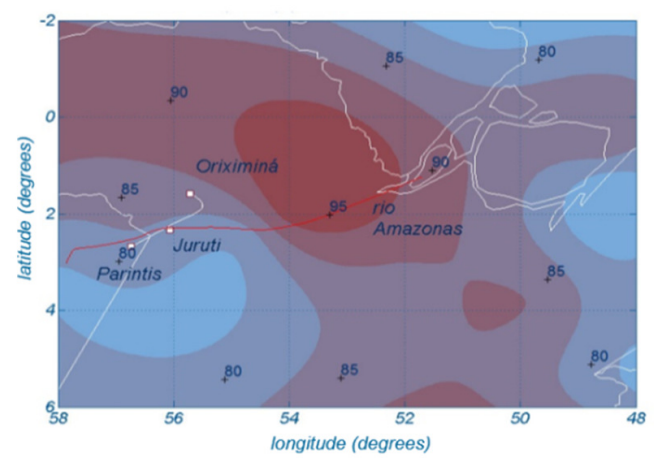

Fig. 2. Isotachs for a return period of 250 years and $10 \mathrm{~min}$ averaging time $(\mathrm{km} / \mathrm{h})$.

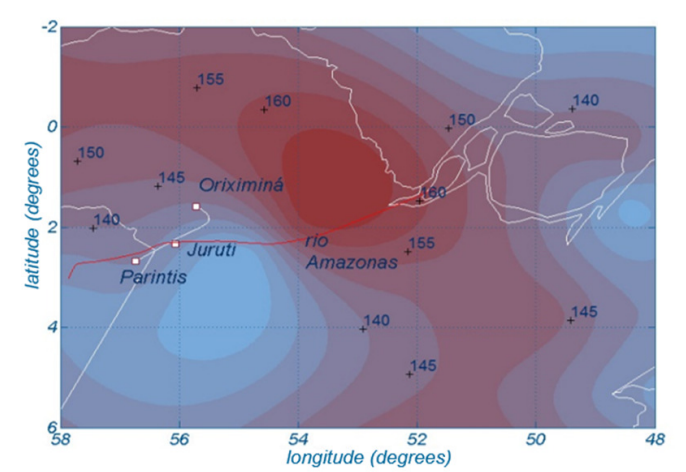

Fig. 3. Isotachs for a return period of 250 years and 3 s averaging time $(\mathrm{km} / \mathrm{h})$.

On this matter, there is a method where milder velocities are used, speeds which, on average, can occur at least once every 2 years simultaneously with power surges. This calls for the use of parameters associated with this rare phenomenon. 
On the other hand, a more realistic analysis methodology that considers the Weibull statistical distribution was used and in order to determine prospective wind velocities aiming to obtain their varied average times and return periods, the mathematical model represented by (1) was utilized.

$$
V_{T}=V m+s(Y-C 2) / C 1
$$

where $Y=-\ln [-\ln (1-1 / T)], V_{T}$ is the wind velocity referring to a return period of $T$ years, $V_{m}$ is the average sample velocity of annual maximums, and $C 1$ and $C 2$ are the coefficients of the Gubel distribution, based on the number of elements.

In the development of the methodology, the average values were corrected according to a study that takes into account the effects of the surplus of turbulence verified in anemometric data in Brazil [14]. This certainly introduces a cautious attitude in the results of forecasted wind velocities, although it is perfectly consistent with the measured data. Samples from just a few years (less than 5 years) result in inferences for 250 years, which rarely exceed a confidence interval of $\pm 20 \mathrm{~km} / \mathrm{h}$ [15-16]. The results presented in Figures 2 and 3 will be used in this study to compare results of unit pressures on the towers and the other components of the transmission lines, according to the guidelines in [9-11].

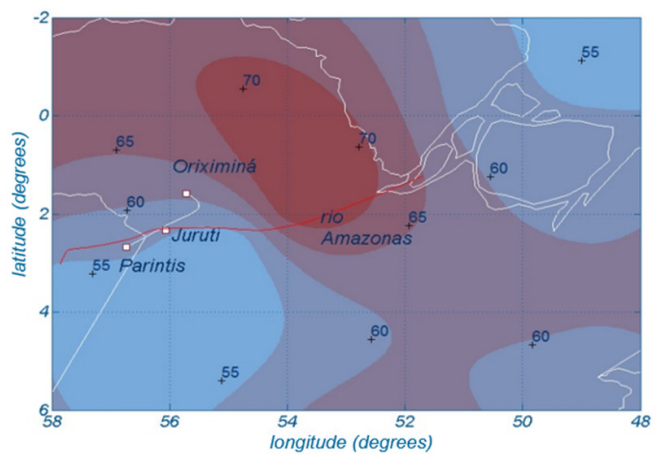

Fig. 4. Isotachs for a return period of 2 years and $30 \mathrm{~min}$ averaging time $(\mathrm{km} / \mathrm{h})$.

\section{B. Atmospheric Correction Factors and Lightning Activity Index}

Similar with wind velocities, other environmental variables influencing structural design were the object of statistical evaluation, as suggested by the most recent standard approaches. In this regard, the following can be mentioned: average and extreme temperatures, relative air densities, relative and absolute humidity, Atmospheric Correction Factors (ACF), regional lightning activity, etc. [17]. Due to their uncontested importance, the ACF variables for $60 \mathrm{~Hz}$ and power surges and the regional lightning levels are given appropriate emphasis. IEC 60060-1 [12] describes in detail the methodology to be followed in the calculation of the ACFs. A systematic calculation with data from several airport collection stations over a period of 10 years provided an accurate evaluation of the statistical moments (means and standard deviations) [18]. Figures 5 and 6 were developed based on the above mentioned data. The $99 \%$ and $90 \%$ safe values for the ACFs of Figures 5 and 6 account for the spatial and temporal variations to which these variables are subject and point out the discrete influence of the gap length in the quantification of the ACFs. The calculation of the national lightning activity was based on maps produced at the Federal University of Rio de Janeiro (UFRJ) and reproduced in the Brazilian standard NBR5422 [19] (Figure 7). Recently ONS published a specific and updated map showing the atmospheric discharges (discharges $/ \mathrm{km}^{2} /$ year) that relate to lightning levels through various formulations (see (2) and (3)). When determining the values of Lightning Activity Levels (LAL), the average of the previously indicated formulations was adopted considering the uncertainties inherent to the phenomenon.

$$
\begin{gathered}
\text { dens }=0.10 \mathrm{NC}, \text { dens }=0.20 \mathrm{NC} \\
\text { dens }=0.04 \mathrm{NC}^{1.25}
\end{gathered}
$$

where dens stands for "discharge density".

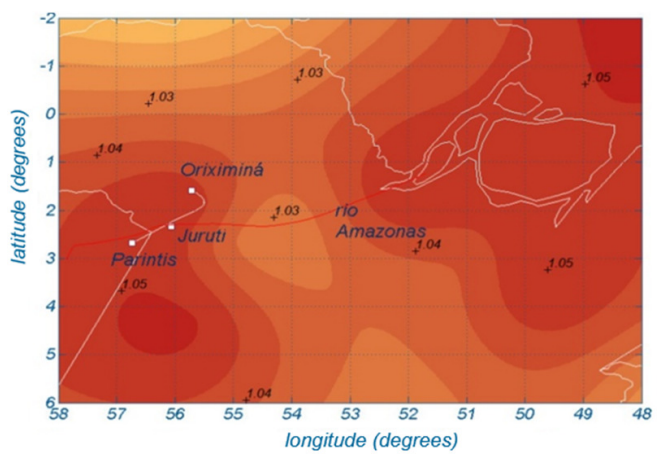

Fig. 5. ACF for $60 \mathrm{~Hz}$ exceeded $99 \%$ of the time.

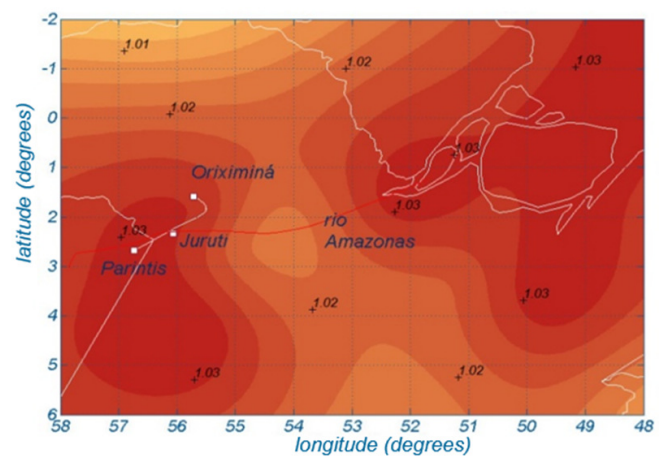

Fig. 6. ACF for power surges exceeded $90 \%$ of the time.

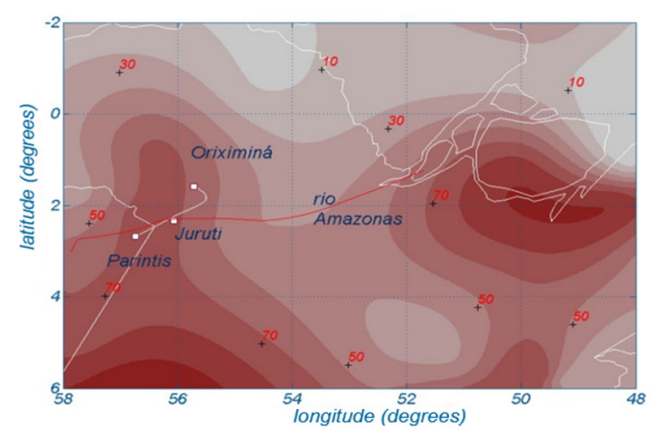

Fig. 7. Number of days with storms in the region. 


\section{STRUCTURE AND COMPONENT CHARACTERISTICS}

In order to broaden the scope of research on current international transmission line design standards, three of the most well-known and most frequently used methods for determining wind pressure on structures and other elements of transmission lines were chosen: IEC 60826 [9], EN 50341-1 [10], and ASCE 74 [11]. The first two use wind velocities collected in $10 \mathrm{~min}$ time spans and the last one is based on $3 \mathrm{~s}$ readings. Theoretically, the three results should have some convergence as they seek strong wind gust loads (storms, cold fronts, or associated systems). The standards IEC $[9,10]$ multiply the values of wind velocities collected in 10min time spans by their gust factors around 1.4-1.6, while the [11] reduces pressure values which result from speeds collected in $3 \mathrm{~s}$ time spans by about $70-80 \%$. Table I and Figure 8 present the general characteristics of the studied crossing. Three solutions were considered regarding the configuration of the conductors: 2xACCC (Monte Carlo), 1xACCC $(25 \mathrm{~mm})$, and 1xCALA 630 (AACSR), with two OPGW shield wires type OPGW DUAL (stainless steel tube in an aluminium tube, on each side of the structure). The cable specifications are shown in Tables II and III. The presented data were adopted in the current work, based on the authors' experience with this type of structural projects, related to challenging spans, when considering transmission line systems commonly observed in river crossings in the Amazon region. It should be noted that the tensions of the OPGW shield wire were defined considering that, for each type of conductor, the sag of the shield wire in the EDS condition equals to $90 \%$ of the sag of the conductor cable in the same condition. This type of ACCC (Aluminium Conductor Composite Core) conductor is quite promising for use in large crossings. Table IV presents the geometric characteristics of the structure, respecting the required electrical safety distances, Table $\mathrm{V}$ shows the calculated wind pressures for the transmission line elements and Figure 8 illustrates the investigated structural system (steel towers and cables). It can be seen in Table IV that the tower heights increase the sag of the adopted conductor cables proportionally (Table II), but the cable-ground electric distance is respected in all the studied configurations.

TABLE I. CHARACTERISTICS OF THE STUDIED CROSSING

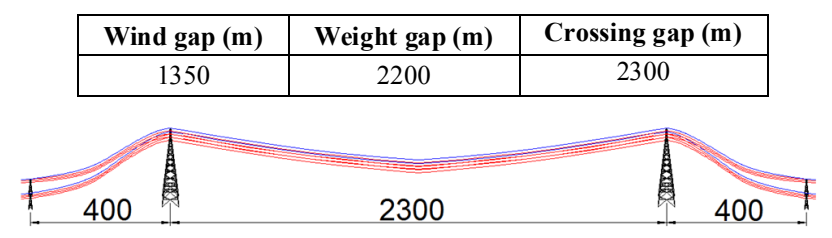

Fig. 8. Investigated structural system (dimensions in $\mathrm{m}$ ).

TABLE II. SPECIFICATIONS OF THE STUDIED CONDUCTORS

\begin{tabular}{|c|c|c|c|c|c|}
\hline Conductors & $\begin{array}{c}\text { Diameter } \\
(\mathbf{m m})\end{array}$ & $\begin{array}{c}\text { Unit } \\
\text { weight } \\
(\mathbf{k N} / \mathbf{m})\end{array}$ & $\begin{array}{c}\text { Rupture } \\
\text { load (kN) }\end{array}$ & $\begin{array}{c}\text { EDS tension } \\
\text { (\% of } \\
\text { rupture load) }\end{array}$ & $\begin{array}{c}\text { Final } \\
\text { EDS } \\
\text { sag (m) }\end{array}$ \\
\hline $\begin{array}{c}\text { 2xACCC } \\
\text { Monte Carlo }\end{array}$ & 20.79 & 0.0078 & 225.70 & 17 & 170 \\
\hline $\begin{array}{c}\text { 1xACCC } \\
\text { 25mm }\end{array}$ & 25.00 & 0.0119 & 247.20 & 17 & 210 \\
\hline $\begin{array}{c}\text { 1xCALA 630 } \\
\text { (AACSR) }\end{array}$ & 36.32 & 0.0332 & 557.91 & 22 & 230 \\
\hline
\end{tabular}

TABLE III. OPGW CABLE SPECIFICATION

\begin{tabular}{|c|c|c|c|}
\hline $\begin{array}{c}\text { OPGW DUAL: } \\
\text { stainless steel tube in } \\
\text { an aluminium tube }\end{array}$ & $\begin{array}{c}\text { Diameter } \\
(\mathbf{m m})\end{array}$ & $\begin{array}{c}\text { Unit weight } \\
\mathbf{( k g} / \mathbf{m})\end{array}$ & $\begin{array}{c}\text { Rupture } \\
\text { load (kN) }\end{array}$ \\
\cline { 2 - 4 } & 24.3 & 0.0239 & 405.40 \\
\hline
\end{tabular}

TABLE IV. MAIN DIMENSIONS OF THE TOWER (m)

\begin{tabular}{|c|c|c|c|}
\hline Conductor types & 2xACCC & 1xACCC & 1xCALA \\
\hline $\begin{array}{c}\text { Horizontal spacing between } \\
\text { phases/shield wires }\end{array}$ & 7.60 & 7.20 & 6.80 \\
\hline Vertical spacing between phases & 11.50 & 11.50 & 11.50 \\
\hline $\begin{array}{c}\text { Vertical spacing between } \\
\text { conductor and shield wires }\end{array}$ & 5.50 & 5.50 & 5.50 \\
\hline Spacing between tower legs & 46.0 & 46.0 & 56.6 \\
\hline Maximum tower height & 233 & 273 & 293 \\
\hline
\end{tabular}

TABLE V. WIND PRESSURES ON CABLES, ISOLATORS AND STRUCTURE $\left(\mathrm{kN} / \mathrm{m}^{2}\right)$

\begin{tabular}{|c|c|c|c|c|c|c|c|c|c|}
\hline \multirow{2}{*}{-} & \multicolumn{3}{|c|}{$\begin{array}{c}\text { 2xACCC } \\
\text { Monte Carlo }\end{array}$} & \multicolumn{3}{c|}{$\begin{array}{c}\text { 1xACCC } \\
\text { 25mm }\end{array}$} & \multicolumn{3}{c|}{$\begin{array}{c}\text { 1xCALA 630 } \\
\text { (AACSR) }\end{array}$} \\
\hline Component & IEC & EN & ASCE & IEC & EN & ASCE & IEC & EN & ASCE \\
\hline Conductors & 0.88 & 0.96 & 0.96 & 0.90 & 1.00 & 0.99 & 0.92 & 1.05 & 1.03 \\
\hline Shield-wires & 0.90 & 0.99 & 0.98 & 0.91 & 1.02 & 1.00 & 0.93 & 1.07 & 1.04 \\
\hline Isolators & 1.35 & 1.53 & 1.26 & 1.38 & 1.56 & 1.27 & 1.42 & 1.61 & 1.29 \\
\hline \multirow{2}{*}{ Structure } & $0.67-$ & $0.54-$ & $0.82-$ & $0.67-$ & $0.53-$ & $0.80-$ & $0.67-$ & $0.53-$ & $0.78-$ \\
& 1.23 & 1.40 & 1.39 & 1.27 & 1.45 & 1.39 & 1.31 & 1.51 & 1.42 \\
\hline
\end{tabular}

Wind pressures are calculated at $10 \mathrm{~m}$ height and at the top of the structure, considering wind actions perpendicular to the transmission line. The other wind pressures are related to the obstacles heights.

\section{APPLIED LOADINGS ON THE INVESTIGATED STRUCTURAL SYSTEM}

The following data show the loading assumptions applied to the structure considering the three studied conductor configurations and the three wind analyzed standards [9-11]. It must be emphasized that the main hypotheses related to the applied loadings on the investigated structural system were calculated using the data presented in section III. Table VI shows the applied loading for each type of cable and wind design standard. The vertical and transversal loads are referred to the extreme transversal wind load case and the longitudinal loads are referred to the conductor and shield-wire break. The storm wind application on the conductors and shield-wires is defined as the $1 / 4$ of the tower's wind gap. The application to high spans becomes less critical than extreme winds considering they are applied across the entire wind gap. Thus, the load related to the conductors and shield-wires for storm winds in high span towers is less relevant than extreme winds.

TABLE VI. APPLIED LOADS ON THE TRANSMISSION LINE

\begin{tabular}{|c|c|c|c|c|c|c|c|c|c|c|}
\hline \multicolumn{11}{|c|}{ Suspension tower loads (kN) } \\
\hline Conductors & \multirow[t]{2}{*}{ Item } & \multicolumn{3}{|c|}{$\begin{array}{c}\text { 2xACCC } \\
\text { Monte Carlo } \\
\end{array}$} & \multicolumn{3}{|c|}{\begin{tabular}{|c|} 
1xACCC ULS \\
$25 \mathrm{~mm}$ \\
\end{tabular}} & \multicolumn{3}{|c|}{$\begin{array}{c}\text { 1xCALA 630 } \\
\text { (AACSR) }\end{array}$} \\
\hline Standard & & IEC & $\mathbf{E N}$ & ASCE & IEC & $\mathbf{E N}$ & ASCE & IEC & \begin{tabular}{|l|}
$\mathbf{E N}$ \\
\end{tabular} & ASCE \\
\hline \multirow{3}{*}{ Conductors } & 1 & 79.4 & 86.7 & 85.7 & 50.9 & 56.5 & 55.0 & 73.2 & 83.3 & 80.6 \\
\hline & 2 & 65.2 & 65.2 & 65.2 & 35.7 & 35.7 & 35.7 & 10.0 & 10.0 & 10.0 \\
\hline & 3 & 63.0 & 64.5 & 64.5 & 46.9 & 48.1 & 47.9 & 105.7 & 107.9 & 107.5 \\
\hline \multirow{3}{*}{$\begin{array}{l}\text { Shield- } \\
\text { wires }\end{array}$} & 4 & 44.4 & 48.7 & 48.3 & 44.9 & 50.2 & 49.2 & 45.8 & 52.6 & 51.2 \\
\hline & 5 & 124.3 & 124.3 & 124.3 & 100.6 & 100.6 & 100.6 & 91.8 & 91.8 & 91.8 \\
\hline & 6 & 71.2 & \begin{tabular}{|l|}
72.2 \\
\end{tabular} & 72.0 & 71.3 & 72.5 & \begin{tabular}{|l|}
72.3 \\
\end{tabular} & 71.5 & 73.0 & 72.7 \\
\hline
\end{tabular}


In this investigation, conductors, shield-wires, and insulators were represented through vertical, transversal, and longitudinal loads, applied at the points of the tower where they were fixed, having in mind the traditional structural analysis methodology currently utilized in design practice. This way, these loads represent the weights, tensions and forces due to the wind action on these elements. Table VI presents the applied loadings on the transmission line system, according to each studied load hypothesis.

\section{STRUCTURAL SYSTEM WEIGHT ESTIMATION}

The approximate weight of the suspension structures for the investigated crossing was estimated, based on the use of empirical formulas developed by the Bonneville Power Administration and existing structures with similar parameters, in terms of application, geometry, and applied loads [21]. This analysis methodology allows the calculation, approximately, of the weight of the transmission line structures, based on their dimensions and acting transverse, vertical, and longitudinal loads, as presented in (4). The mathematical formulation has used a constant, which is defined by applying it to a structure with similar characteristics to the studied one and with a calculated weight. Once the constant is defined, (4) is applied to the studied structure with its dimensions and acting loads, obtaining an approximate weight, based on the study of other similar structures [21].

$$
W_{e}=C k_{p}\left(\frac{h}{0.3048}\right)\left(\left(\frac{T}{4.4482}\right)^{2 / 3}+\left(\frac{V}{0.4482}\right)^{1 / 2}+\left(\frac{L}{0.4482}\right)^{2 / 3}\right) 4.482
$$

where $W_{e}$ it the approximate weight of the structure $(\mathrm{N}), C$ is a constant calculated using the adopted reference tower, $h$ is the ground height to the centre of gravity loads acting on conductors (m), $T$ is the total transverse load $(\mathrm{N}), V$ is the total vertical load $(\mathrm{N}), L$ it the longitudinal load $(\mathrm{N})$, and $k_{p}$ is a variable depending on the distance between phases and tower function. For suspension towers: $k_{p}=\left(1.44+(B / 0.3048)^{2}\right)^{1 / 2}$ and for anchor towers: $k_{p}=\left(2.89+(B / 0.3048)^{2}\right)^{1 / 2}$, where $B$ is the distance between phases $(\mathrm{m})$.

Thus, a relationship can be established considering already existing crossings, making an interactive calculation between the formulation in [21] and the investigated towers. It must be emphasized that the reference towers have considered all the connection plates, bolts, and/or welds used in this type of structure. The load cases applied on the reference towers were including all the hypotheses usually considered on this type of towers, including extreme winds, thunderstorm winds, construction, and assembly. Table VII presents the total weight of the analyzed suspension towers.

TABLE VII. SUSPENSION TOWER WEIGHT $(\mathrm{kN})$

\begin{tabular}{|c|c|c|c|c|c|c|c|c|c|}
\hline Conductors & \multicolumn{3}{|c|}{$\begin{array}{c}\text { 2xACCC } \\
\text { Monte Carlo }\end{array}$} & \multicolumn{3}{|c|}{$\begin{array}{c}\text { 1xACCC ULS } \\
\text { 25mm }\end{array}$} & \multicolumn{3}{c|}{$\begin{array}{c}\text { 1xCALA 630 } \\
\text { (AACSR) }\end{array}$} \\
\hline Standards & IEC & EN & ASCE & IEC & EN & ASCE & IEC & EN & ASCE \\
\hline $\begin{array}{c}\text { Tubular } \\
\text { Tower }\end{array}$ & 3,454 & 3,821 & 3,924 & 4,289 & 4,823 & 4,962 & 5,268 & 5,883 & 6,032 \\
\hline $\begin{array}{c}\text { Angle } \\
\text { Tower }\end{array}$ & 4,605 & 5,095 & 5,232 & 5,718 & 6,431 & 6,617 & 7,023 & 7,845 & 8,043 \\
\hline
\end{tabular}

It can be seen from Table VII that the tower formed by angle profiles presents a weight about $30 \%$ heavier than those composed by tubular profiles. This is due to the fact that tubular profiles present geometric characteristics with greater resistance to buckling, resulting in less need for bracing and although the drag coefficient of tubular profiles is higher than that of angle profiles, the tubular tower has smaller wind act areas. Comparing the three cable solutions presented, the 1xCALA 630 solution (AACSR) results in a $22 \%$ heavier structure than the 1xACCC ULS $25 \mathrm{~mm}$ solution, which in turn was $25 \%$ heavier than the tower which adopted $2 \times A C C C$ Monte Carlo, although the loads increase respectively, what determined the weight increase in the structures was their height and not the applied loadings.

\section{STRUCTURAL DESIGN COMPARISON}

The typical structures of transmission lines in general are designed with angular profiles, however due to the higher resistance to buckling and less need for secondary bracing, the tubular profiles are usually applied to high towers, as shown in Table VIII.

TABLE VIII. LONG SPAN TRANSMISSION LINES IN CHINA [22]

\begin{tabular}{|c|c|c|c|c|}
\hline Project Name & $\begin{array}{c}\text { Voltage } \\
\text { Level }\end{array}$ & $\begin{array}{c}\text { Tower } \\
\text { Height (m) }\end{array}$ & Tower Structure & $\begin{array}{c}\text { Built } \\
\text { Time }\end{array}$ \\
\hline Zhoushan & $220 / 500 \mathrm{kV}$ & 370.00 & $\begin{array}{c}\text { Steel tube \& concrete } \\
\text { filled steel tube }\end{array}$ & $\begin{array}{c}\text { Jun., } \\
2010\end{array}$ \\
\hline Jiangyin & $500 \mathrm{kV}$ & 346.50 & $\begin{array}{c}\text { Welding cross steel } \\
\text { plate }\end{array}$ & $\begin{array}{c}\text { Nov. } \\
2004\end{array}$ \\
\hline $\begin{array}{c}\text { Nanjing } \\
\text { Shanjiangkou }\end{array}$ & $500 \mathrm{kV}$ & 294.50 & Steel tube & $\begin{array}{c}\text { Feb., } \\
2007\end{array}$ \\
\hline $\begin{array}{c}\text { Nanjing } \\
\text { Dashengguan }\end{array}$ & $500 \mathrm{kV}$ & 257.00 & $\begin{array}{c}\text { Reinforcement } \\
\text { concrete }\end{array}$ & $\begin{array}{c}\text { Jun., } \\
2000\end{array}$ \\
\hline $\begin{array}{c}\text { Nanjing } \\
\text { Shangjiankou }\end{array}$ & $500 \mathrm{kV}$ & 249.50 & Steel tube & $\begin{array}{c}\text { Jun., } \\
2005\end{array}$ \\
\hline $\begin{array}{c}\text { Shanghao } \\
\text { Wusongkou }\end{array}$ & $500 \mathrm{kV}$ & 177.50 & Steel tube & $\begin{array}{c}\text { Jul., } \\
2003\end{array}$ \\
\hline $\begin{array}{c}\text { Hangzhou } \\
\text { Qianjiang }\end{array}$ & $500 \mathrm{kV}$ & 128.00 & Steel tube & $\begin{array}{c}\text { Jun., } \\
2004\end{array}$ \\
\hline Wuhu & $500 \mathrm{kV}$ & 229.00 & Steel tube & $\begin{array}{c}\text { Sep., } \\
2002\end{array}$ \\
\hline Fuzhou Minjiang & $500 \mathrm{kV}$ & 107.64 & Steel tube & $\begin{array}{c}\text { Jul., } \\
2002\end{array}$ \\
\hline Luohe Long & $500 \mathrm{kV}$ & 161.38 & Reinforcement \\
concrete & $\begin{array}{c}\text { Apr., } \\
1989\end{array}$ \\
\hline Nanjing Yanziji & $220 \mathrm{kV}$ & 195.50 & Steel tube & $\begin{array}{c}\text { Sep., } \\
1976\end{array}$ \\
\hline
\end{tabular}

In accordance with the most commonly used power level configurations, the 1xCALA 630 cable was adopted in the structural design of the investigated suspension tower. The applied wind design standard was EN 50341-1 [10], because it is for general use, and it can be applied to this type of structure. ASCE-10 [23] was the adopted structural design standard for angle profiles, and NBR 8800 [24] for tubular profiles. The steel transmission tower was numerically modelled applying the Finite Element Method (FEM), using the PLS Tower and Strap computational programs. Figure 9 illustrates the investigated structural model and the modeling of the tower geometry. In this investigation, the conductors, shield-wires, and insulators were represented based on the use of vertical, transversal, and longitudinal loads, as mentioned above, in order to adopt the very traditional structural design analysis methodology, currently used in day-to-day practice. 


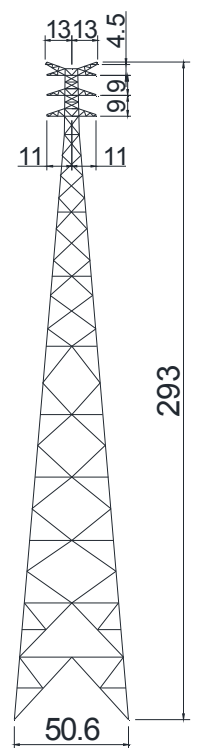

(a)

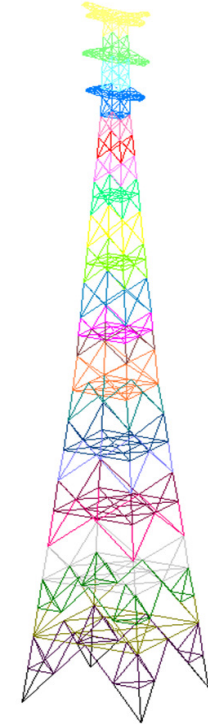

(b)

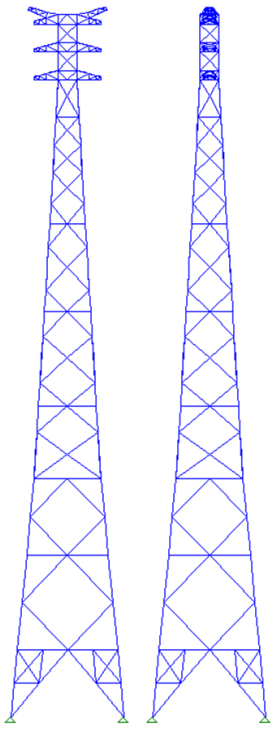

(c)
Fig. 9. Investigated structural model (dimensions in $\mathrm{m}$ ) and finite element models: (a) geometry, (b) tower composed by angle profiles in PLS Tower, (c) tower composed by tubular profiles in Strap

The steel tower's structural system was modeled with the use of angle profiles (PLS Tower) and with tubular profiles (Strap). The structural system using tubular profiles requires fewer bracings, since the geometric properties of tubular components have a higher resistance to buckling. On the other hand, the secondary bracing has the function of reducing the buckling length in towers. By disposing some of these secondary elements and considering the design based on the use of tubular profiles, the final result is a lighter tower. Table IX presents the results of the steel tower structural design (most loaded main legs of the tower), considering angle and tubular profiles respectively, emphasizing that in both analyses, type ASTM A572 GR60 steel was used.

TABLE IX. STRUCTURAL RESPONSE OF THE STEEL TOWER DESIGN: AN GLE PROFILES VERSUS TUBULAR PROFILES

Tower main legs composed of angle profiles: $4 L 203 \times 203 \times 19.1 \mathrm{~mm}$ \begin{tabular}{|l|l|l|l|l|l|l|l|l|l|l|}
\hline Weight & $A l$ & $A g$ & $R$ & $L$ & $\lambda e$ & $f y$ & Ncres & Ntres & $N c$ & $N t$ \\
\hline
\end{tabular}

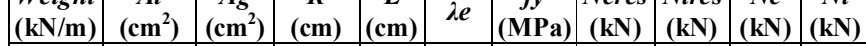
\begin{tabular}{|l|l|l|l|l|l|l|l|l|l|l|}
\hline 2.28 & 267.8 & 295.2 & 6.27 & 600 & 96 & 414 & 8,924 & 9,944 & 7,100 & 2,756 \\
\hline
\end{tabular} Tower main legs composed of tubular sections: diameter $356 \mathbf{~ m m}$ \begin{tabular}{|l|l|l|l|l|l|l|l|l|l|l|}
$t$ & Weight & Ag & $I$ & $r$ & $L$ & fy & Ncres & Ntres & Nc & Nt
\end{tabular} \begin{tabular}{l|l|l|l|l|l|l|l|l|l|l|}
$(\mathbf{c m})$ & $(\mathrm{kN} / \mathrm{m})$ & $\left(\mathrm{cm}^{2}\right)$ & $\left(\mathrm{cm}^{4}\right)$ & $(\mathbf{c m})$ & $(\mathbf{c m})$ & $(\mathbf{M P a})$ & $(\mathrm{kN})$ & $(\mathbf{k N})$ & $(\mathrm{kN})$ & $(\mathrm{kN})$ \\
\hline
\end{tabular} \begin{tabular}{l|l|l|l|l|l|l|l|l|l|l|}
2.22 & 1.82 & 232.5 & 32,451 & 11.9 & 800 & 414 & 6,433 & 6,620 & 5,256 & 1,893 \\
\hline
\end{tabular} $A l$ : net area, $A g$ : gross area, $r$ : spin radius, $L$ : buckling length, $\lambda e$ : effective slenderness, $f y$ : steel flow tension, $t$ : thickness, $I$ : moment of inertia, $D$ : diameter of the tubular profile, Ncres/Ntres: resistan compression load/resistant tension load, $N c / N t$ : active compression/tension load.

This way, considering the tower designed with tubular profiles as a reference, and comparing this structure with the tower formed by angle profiles, it was concluded that tower structure using tubular profiles presents a $30 \%$ material weight reduction, as presented in Table VIII. The tubular geometry also allows lower drag coefficients, resulting in lower wind loads, reducing the forces acting on the structures and the displacements values. Based on the results presented in Table IX, it is possible to see that the compression loads $(N c)$ on the main legs of the tubular steel towers are smaller due to the lighter weight of the structure and the lower drag coefficient. Keeping in mind that the weld joining the flange to the tubular profile is twice as long as the width of the plate, so there is no reduction in the effective section $(C t=1)$. Thus, even with a smaller profile area, the tension resistance assumes a significant value. In addition to the tubular profile of the main legs presenting greater buckling length, its linear weight is lighter than the profile composed of angles.

\section{CONCLUSIONS}

This study aims to develop an analysis methodology in order to make structural optimizations compatible with large existing river crossings. This way, a crossing situated at the northern region of Brazil, with a 2,300m span between its banks was investigated. Initially, the environmental parameters were defined, such as the wind speed and ACFs. Then, the structural solutions were applied using three electrically equivalent different conductor configurations: 2xACCC Monte Carlo, 1xACCC 25mm, and 1xCALA 630 (AACSR) and three different commonly used wind standards: IEC 60826 [9], EN 50341-1 [10], and ASCE 74 [11]. Afterwards, the estimated structural weight was presented for all the above mentioned cases and for structures composed of tubular and angle profiles. The structural design of the tower was considered through the use of tubular and angle profiles for the most common conductor configuration of the studied power level: 1xACCC 630 cable (AACSR) and wind standard EN 50341-1 [10]. Firstly, with regard to the statistical calculations of the RADs (Relative Air Density) and ACFs it should be noted that for the purpose of transmission line projects, the methodology used for analysis can be improved by adding more meteorological stations. Considering future wind velocity assessments to be more realistic in swing angle calculations, migrating from Gumbel to Weibull distribution can be supported by practical data. Decisions involving power surges associated with powerup and restarting must be refined so that current operational needs are met.

Extrapolating the limitations in design standards for maximum support heights $(60 \mathrm{~m})$ should be so advanced that the vertical wind profile in the case of long crossings would be carried out with greater precision. This way, there are two immediate actions that can be taken: a) Installing, in the short term, anemometers in the aforementioned installations at three distinct heights (e.g. at $10 \mathrm{~m}$, at the mid height of the conductors, and at the top of the structures). Modern collection systems can carry out velocity and direction readings every second and store them locally or remotely. b) A national archive consisting of data previously collected from wind farms, where the heights of the generators reach hundreds of meters. As an extension of this procedure, transmission lines considered more strategically important could similarly be equipped with the same wind measurement systems that are suggested here. In this way, the national experience with extreme wind velocities could be improved and consolidated. The problems with the approach regarding the transmission capacity of the transmission lines (ampacity) could be benefited by the adoption of the suggested collection system, using models of low wind velocities and dominant directions. 
The structural pre-design and the interface between all areas of a basic project are relevant for a successful final outcome. Thus, this research has studied several structures. The weights of these structures have been calculated using practical and widely accepted methods. After this study, the weights were verified for the chosen structure using numerical modeling compatible with the desired precision, taking the process to the expected definition of global geometry and behavior of the structure. When the structural design was investigated with the use of the developed analysis methodology, it was concluded that the optimum solution was obtained with the use of the tubular structural system, which presented better performance when compared to the angle structures, with a relevant material weight reduction equal to $30 \%$. It is worth mentioning that ACCC-type cables, although still in their development phase, are quite promising for use in long crossings which is the object of this study.

Finally, it is important to emphasize on the intention to perform a more refined finite element modeling of the crossing, aiming to represent the cables. This way, nonlinear dynamic analysis should be performed in order to evaluate the dynamic structural behavior of the system. The problem is certainly much more complicated and influenced by the nonlinear dynamic response of the cables, and in sequence further research will be carried out in this area.

\section{ACKNOWLEDGEMENTS}

The authors gratefully acknowledge the financial support provided by the Brazilian Science Foundation's CAPES, CNPq and FAPERJ.

\section{REFERENCES}

[1] D. Pylarinos, "Overhead Transmission Line Easement and Right-of-Way Cases in Crete, Greece: A Statistical Analysis of 1220 Cases from 1974 to 2019," Engineering, Technology \& Applied Science Research, vol. 10, no. 3, pp. 5581-5589, Jun. 2020, https://doi.org/10.48084/etasr.3591.

[2] W. M. Frota, "Melhorias estruturais de suprimento para os sistemas elétricos isolados de Manaus e Macapá," T\&C Amazonia, vol. 3, no. 6, pp. 23-29, 2005.

[3] G. N. D. Boile and R. L. Nascimento, "Linhão Tucuruí-1800 km de integração regional," Revista T\&D Amazonia, vol. 8, no. 18, pp. 58-62, 2010 .

[4] J. N. M. Motta, "Análise do comportamento estrutural de grandes travessias em linhas de transmissã," Ph.D. dissertation, Fluminense Federal University, Niterói, Brazil, 2015.

[5] A. L. Silva and A. L. Sales Neto, "Desafio Amazônico - A Complexidade de Manutenção na faixa de Servidão das Linhas de Transmissão Oriximiná - Silves e Silves - Lechuga," presented at the XXIII SNPTEE, Brazil, 2015.

[6] M. S. Rechtman, “Análise dinâmica não determinística de torres de telecomunicações submetidas à ação do vento," M.S. thesis, Fluminense Federal University, Niterói, Brazil, 2018.

[7] A. J. G. Pinto, E. C. M. Costa, S. Kurokawa, and J. Pissolato, “Analysis of the Electrical Characteristics of an Alternative Solution for the Brazilian-Amazon Transmission System," Electric Power Components and Systems, vol. 39, no. 13, pp. 1424-1436, Aug. 2011, https://doi.org/10.1080/15325008.2011.584106.

[8] A. J. G. Pinto, E. C. M. Costa, S. Kurokawa, J. H. A. Monteiro, J. L. de Franco, and J. Pissolato, "Analysis of the electrical characteristics and surge protection of EHV transmission lines supported by tall towers," International Journal of Electrical Power \& Energy Systems, vol. 57, pp. 358-365, May 2014, https://doi.org/10.1016/j.ijepes.2013.12.015.
[9] Design criteria of overhead transmission lines, IEC 60826:2017, International Electrotechnical Commission, Switzerland, 2017.

[10] Overhead electrical lines exceeding AC $1 \mathrm{kV}$ - Part 1: General requirements - Common specifications, CENELEC - EN 50341-1, CENELEC, Belgium, 2012.

[11] C. J. Wong and M. D. Miller, Guidelines for Electrical Transmission Line Structural Loading, 3rd ed. Reston, VA: American Society of Civil Engineers, 2009.

[12] High-voltage test techniques - Part 1: General definitions and test requirements, EN 60060-1:2010, International Electrotechnical Commission, Switzerland, 2010.

[13] C. R. Gontijo, “Contribuição à análise e projeto de torres autoportantes de linhas de transmissão," M.S. thesis, Federal University of Minas Gerais, Belo Horizonte, Brazil, 1994.

[14] J. I. Silva Filho, L. A. M. C. Domimgues, A. A. Menezes, and A. P. Ruffier, "Assessment of Environmental Statistics as an Accessible Breakthrough to Improve Ohtls Design," in Proceedings CIGRE Session 2006, Paris, France, 2006.

[15] G. R. Kendall, "Statistical analysis of extreme values," presented at the First Canadian Hydrology Conferenc, Canada, 1959.

[16] B. M. Alshammari, "Probabilistic Evaluation of a Power System's Reliability and Quality Measures," Engineering, Technology \& Applied Science Research, vol. 10, no. 2, pp. 5570-5575, Apr. 2020, https://doi.org/10.48084/etasr.3441.

[17] S. Kurokawa, E. C. M. Costa, A. J. G. Pinto, and J. P. Filho, "Analysis of Electric Characteristics of High-Elevation Stretches of the TucuruíMacapá-Manaus Connection," Journal of Control, Automation and Electrical Systems, vol. 24, no. 5, pp. 714-724, Oct. 2013, https://doi.org/10.1007/s40313-013-0059-5.

[18] R. M. Azevedo, J. I. Silva Filho, and V. H. G. Andrade, "Fatores de correção atmosféricos aplicados ao dimensionamento de isolamentos em ar - Nova metodologia de cálculo," presented at the XVII SNPTEE, Andrade, Brazil, Oct. 2003.

[19] Projeto de linhas aéreas de transmissão e sub-transmissão de energia elétrica, ABNT NBR 5422:1972, ABNT - Associação Brasileira de Normas Técnicas, Brazil, 1972.

[20] O. A. C. Amarantes, J. Zack, M. Brower, and A. L. de Sá, Atlas do Potencial Eólico Brasileiro. Brasilia, Brasil: Ministerio de Minas e Energia, 2001.

[21] M. Marjerrison, "Electric Transmission Tower Design," Journal of the Power Division, vol. 94, no. 1, pp. 1-23, 1968.

[22] Z. Lin, D. Zhang, G. Dai, B. Li, C. Whang, and W. Zhao, "Design, Fabrication and Erecting of the Long Span Transmission Tower for Crossing the Amazon River of $500 \mathrm{kV}$ TL Tucuruí - Xingu - Jurupari Oriximiná," presented at the 2014 Cigrè Canada Conference, Toronto, Canada, Sep. 2014.

[23] Design of Latticed Steel Transmission Structures, ASCE 10, ASCE, Reston, VA, USA, 2015.

[24] Projeto de Estruturas de Aço e de Estruturas Mistas de Aço e Concreto de Edifícios, NBR 8800: 2008, ABNT - Associação Brasileira de Normas Técnicas, Brazil, 2008. 